\title{
ŁUKASZ KISZKIEL
}

UNIWERSYTET W BIAŁYMSTOKU

E-MAIL: LUKASZKISZKIEL@GMAIL.COM

\section{ASPIRACJE EDUKACYJNE, ZAWODOWE I ŻYCIOWE BIAŁOSTOCKICH MATURZYSTÓW W LATACH 2010-2015}

\section{Wprowadzenie}

Uczniowie klas maturalnych są postawieni przed niezwykle złożonym wyzwaniem. Znajdując się na progu dorosłości, zmuszeni są do podejmowania decyzji związanych z własną przyszłością. Opierając się na dostępnych informacjach, posiadanych preferencjach i zasobach, nabytych umiejętnościach i wiedzy, rekomendacjach znaczących innych (rodziców, nauczycieli, znajomych) i pozostałych subiektywnych czynnikach, dokonują oni kilkuetapowego wyboru dotyczącego ich dalszej kariery. Pierwszym z nich jest decyzja o kontynuowaniu lub zaniechaniu edukacji i próba podjęcia pracy zawodowej. Kolejnym jest wybór kierunku studiów oraz ośrodka akademickiego, w którym pobierana będzie nauka. Dokonane na tym etapie życia decyzje będą silnie determinowały prawdopodobieństwo realizacji planów, aspiracji i celów jednostki, pojmowanych szeroko jako sukces życiowy, zarówno w jej subiektywnym, jak i zobiektywizowanym sensie. W tym artykule przedstawione zostaną wyniki badań białostockich maturzystów dotyczące ich aspiracji edukacyjnych, zawodowych i życiowych oraz subiektywnej oceny szans ich realizacji.

\section{Definiowanie sukcesu życiowego}

Augustyn Bańka [2005] stwierdza, że podstawą sukcesu nie jest jednorazowy akt wyboru kariery, ale umiejętność jej etapowego budowania, modyfikowania oraz w konsekwencji wdrażania własnych planów w życie. Sukces edukacyjny, który nierzadko implikuje sukces zawodowy, wymaga zatem przyjęcia określonej strategii, a następnie jej konsekwentnej realiza- 
cji. Strategie oraz definicja sukcesu życiowego jest modyfikowana między innymi przez status materialny czy pochodzenie społeczne - inny punkt widzenia będą prezentować maturzyści $\mathrm{z}$ niezamożnych i zamożnych rodzin, pochodzący ze wsi i miasta, bądź uczęszczający do renomowanych i nierenomowanych szkól, a także pochodzących z rodzin o wysokim kapitale społecznym.

Co więcej, na osiągnięcie sukcesu edukacyjnego, zawodowego i życiowego wpływać będą zarówno czynniki wewnętrzne na przykład cechy charakteru, czyli motywacja, ambicja, determinacja, pracowitość, ale także indywidualizm lub konformizm, rozumiany jako dostosowywanie własnych decyzji do opinii znaczących innych. Rolę odgrywają również czynniki „zewnętrzne”: rodzice, rodzina, środowisko, z którego wywodzi się człowiek, kapitał kulturowy, który jest nierzadko skorelowany z kapitałem ekonomicznym. Cała ta mozaika wewnętrznych i zewnętrznych czynników determinuje określony styl życia jednostki. Może być on rozumiany jako alternatywne sposoby funkcjonowania wynikające $\mathrm{z}$ pochodzenia społecznego, posiadanych cech społecznych oraz ze zróżnicowanego dostępu do dóbr i usług [Johnson 1997]. Według A. Adlera [2000] styl życia to jedyny w swoim rodzaju, wywierający wpływ na otoczenie sposób bycia danej osoby, na który składa się całość motywów, cech, zainteresowań i wartości uznawanych i przejawianych poprzez zachowanie konkretnej osoby. Reprezentowane style życia przekładają się istotnie na aspiracje (decyzje) edukacyjne i zawodowe maturzystów, które następnie determinują ich życiowy sukces. Czym jest jednak ów życiowy sukces?

Przyglądając się młodzieży M. Pinquarta i R. Silbereisen [2010] wyodrębnili trzy kluczowe, subiektywne kryteria definiujące życiowy sukces: po pierwsze, sukces w wymiarze zawodowym - rozumiany jako subiektywne odczucie postępu własnej kariery, sukces w wymiarze społecznym (afiliacyjnym), czyli zadowolenie $\mathrm{z}$ relacji osobistej ze znaczącymi innymi oraz sukces w wymiarze samorealizacji - pojmowany jako podejmowanie działań motywujących powiązanych ze spędzaniem wolnego czasu.Jak zauważa Hildebrandt-Wypych za H. Meulemann [2011], „sukces życiowy jest mierzony tą samą 'obiektywną' skalą: stadiami kariery zawodowej i życia prywatnego, a miejsce na owej skali jest instytucjonalnie powiązane $\mathrm{z}$ zasobami - pieniędzmi, szacunkiem i prestiżem. 'Obiektywny' sukces życiowy nabiera kolorów dzięki 'subiektywnym' strategiom jego ewaluacji”. Satysfakcja 
życiowa zależy zatem nie tylko od obiektywnej walidacji faktu, że życie określonej jednostki jest szczęśliwe (że „odniosła sukces”), ale także od indywidualnej, dokonywanej wielokrotnie, subiektywnej oceny, że sukces życiowy stał się jej udziałem.

W zrealizowanym badaniu białostockich maturzystów autorzy starali się uchwycić nastawienie i subiektywną ocenę młodzieży wobec realizacji życiowych scenariuszy. Dotyczą one społecznie uznawanych wyznaczników sukcesu i odnoszą się do scharakteryzowanych powyżej wymiarów zaproponowanych przez M. Pinquarta i R. Silbereisen (m.in. ukończenie studiów, posiadanie wymarzonej pracy, założenie rodziny, przynależność do elity, bycie zamożnym). Dodatkowo, aby sprawdzić na ile trwałe są deklaracje uczniów porównano dwa pomiary dokonane w 2010 i 2015 roku.

\section{Strategie podejmowania decyzji wpływających na realizację aspiracji maturzystów}

Aby sprawdzić, czy maturzyści planują swoją przyszłość rozsądnie (racjonalnie) i wierzą we własne sprawstwo, czy też ulegają emocjom, opiniom rodziny i uważają, że niewiele od nich zależy, przedstawiono im listę stwierdzeń obrazujących, jak inni ludzie radzą sobie w rozmaitych sytuacjach wyboru. Badanych poproszono, aby określili, na ile każde stwierdzenie trafnie reprezentuje ich poglądy. Za model wyjściowy posłużyła analiza dokonana przez J. Poleszczuka (2013), w której przy użyciu analizy czynnikowej początkowe trzydzieści dwa stwierdzenia zredukowano do dziewięciu wymiarów prezentujących odmienne strategie decyzyjne maturzystów. Były to:

Tabela 1. Strategie podejmowania decyzji w celu realizacji życiowych planów (aspiracji)

\begin{tabular}{|l|}
\hline CDS (Carpe Diem) \\
\hline $\begin{array}{l}\text { Maturzyści wyznający maksymę Horacego, wyrażali przekonanie, że życia nie da się zaplanować. } \\
\text { Stwierdzenia z tego czynnika ogniskowały się wokół ogólnej postawy braku sprawstwa i nieprze- } \\
\text { widywalności jaką niesie los }\end{array}$ \\
\hline JA (Samoocena) \\
\hline $\begin{array}{l}\text { Badani aprobujący tą postawę, częściej drobiazgowo planowali własne działania, rozpatrując jak } \\
\text { największe spektrum możliwych alternatyw oraz rozważając przyszłe konsekwencje dokonanych } \\
\text { wyborów. Po wytyczeniu celu, skupiali na nim całą uwagę }\end{array}$ \\
\hline
\end{tabular}


cd. Tabela 1.

\begin{abstract}
RAT (Racjonalność)
Maturzyści kierujący się racjonalnym oglądem posiadanych alternatyw, realizowali skutecznie zamierzone cele, doceniali konsekwencję w działaniu i nie żałowali podjętych decyzji. Przejawianie postawy racjonalnej wiązało się z odrzucaniem przypadku i życia chwilą - odwrotnie racjonalność wymagała orientacji na przyszłość, na to, co się chce osiągnąć przez realizację zaplanowanego działania
\end{abstract}

\title{
IND (Indywidualizm)
}

Maturzyści przejawiający cechy indywidualistyczne, byli nonkonformistyczni i nie lubili kiedy otrzymywali rady od innych. Uznawali, że aby coś osiągnąć, należy liczyć wyłącznie na siebie, a przy tym nie trzeba zbytnio ufać innym.

\section{LID (Rola lidera)}

Liderzy, to osoby lubiące w sytuacjach problemowych decydować za grupę, z poczuciem przywództwa objawiającego się naśladownictwem ich zachowań przez pozostałych członków, a także posiadający przekonanie, że mają większe szanse na realizację własnych celów życiowych niż koledzy

\section{SOC (Orientacja społeczna)}

To badani częściej wyznający przekonanie, że podczas podejmowania decyzji, warto rozważyć jak postąpiliby w takiej sytuacji inni

\section{KON (Kontrola)}

Byli to maturzyści, mający poczucie zbyt daleko posuniętej rodzicielskiej kontroli oraz posiadający rodziców z wyraźnymi oczekiwaniami, co do dalszych planów jednostki

\section{WSP (Wsparcie społeczne)}

Badani, którzy zgadzali się, że przed podjęciem istotnej decyzji warto jest porozmawiać z zaufaną osobą. Ponadto, mogli oni liczyć na wstawiennictwo (protekcję) rodziców w trudnej sytuacji

\section{SPR (Sprawczość)}

Silne ukierunkowanie na własne możliwości i wiarę we własne działania. Przyczyn błędnych decyzji, zdaniem badanych, należy upatrywać w nas samych

Źródło: http://soc.uwb.edu.pl/images/matura/Raport_Matura_i_co_dalej_Edycja_2010.pdf, s. 26-34.

Następnie odtworzono procedurę analityczną z zastosowaniem analizy czynnikowej, traktując jako podstawę obliczeń zagregowane pomiary (z 2010 roku i 2015 roku), a następnie dokonano porównania uzyskanych czynników za pomocą testu t-Studenta dla parametrycznych prób niezależnych. 
Tabela 2. Porównanie strategii decyzyjnych $\mathrm{w}$ dwóch pomiarach

\begin{tabular}{|c|c|c|c|c|c|}
\hline Czynniki & Rok & $\mathrm{N}$ & Średnia & SD & $\mathrm{t}$ \\
\hline \multirow{2}{*}{ CDS (Carpe Diem) } & 2015 & 1197 & 0,05 & 0,98 & \multirow{2}{*}{$2,44^{*}$} \\
\hline & 2010 & 1099 & $-0,05$ & 1,02 & \\
\hline \multirow{2}{*}{ JA (Samoocena) } & 2015 & 1206 & $-0,02$ & 0,99 & \multirow{2}{*}{$-0,81$} \\
\hline & 2010 & 1110 & 0,02 & 1,01 & \\
\hline \multirow{2}{*}{ RAT (Racjonalność) } & 2015 & 1220 & 0,01 & 1,00 & \multirow{2}{*}{0,33} \\
\hline & 2010 & 1116 & $-0,01$ & 1,00 & \\
\hline \multirow{2}{*}{ IND (Indywidualizm) } & 2015 & 1219 & $-0,04$ & 1,00 & \multirow{2}{*}{$-2,00^{*}$} \\
\hline & 2010 & 1112 & 0,04 & 0,99 & \\
\hline \multirow{2}{*}{ LID (Rola lidera) } & 2015 & 1216 & $-0,02$ & 1,00 & \multirow{2}{*}{$-1,19$} \\
\hline & 2010 & 1126 & 0,03 & 1,00 & \\
\hline \multirow{2}{*}{ SOC (Orientacja społeczna) } & 2015 & 1220 & $-0,02$ & 1,00 & \multirow{2}{*}{$-1,05$} \\
\hline & 2010 & 1130 & 0,02 & 1,00 & \\
\hline \multirow{2}{*}{ KON (Kontrola) } & 2015 & 1216 & $-0,03$ & 1,03 & \multirow{2}{*}{$-1,45$} \\
\hline & 2010 & 1126 & 0,03 & 0,97 & \\
\hline \multirow{2}{*}{ WSP (Wsparcie społeczne) } & 2015 & 1218 & 0,00 & 1,01 & \multirow{2}{*}{0,12} \\
\hline & 2010 & 1127 & 0,00 & 0,99 & \\
\hline \multirow{2}{*}{ SPR (Sprawczość) } & 2015 & 1217 & $-0,05$ & 1,08 & \multirow{2}{*}{$-2,31^{\star}$} \\
\hline & 2010 & 1129 & 0,05 & 0,91 & \\
\hline
\end{tabular}

Źródło: Badania Matura i co dalej?, porównanie edycji 2010 i 2015.

Powyższe porównanie przynosi ciekawe wnioski. Okazuje się, że w późniejszym pomiarze, wzrosła liczba osób zasilających czynnik Carpe Diem, ogniskujący światopogląd wyrażający się brakiem refleksji nad własną przyszłością. Charakteryzuje go nieposiadanie wyraźnych aspiracji życiowych i przyjmowanie fatalistycznej postawy względem własnych możliwości, w myśl przekonania: „poddam się temu co przyniesie los, ponieważ i tak nie mam na nic wpływu". Z drugiej strony spada liczba indywidualistów (IND) oraz maturzystów, którzy silne wierzą w swoje możliwości (SPR). Są to osoby, które czują się kowalami własnego sukcesu, a realizację aspiracji edukacyjnych i zawodowych uzależniają od własnej pracy.

Przeanalizowane tu dwa pomiary zrealizowane w stosunkowo krótkim odstępie czasu (5 lat) nie dają pewności, że opisywane zmiany są trwałe. Jeśli jednak maturzyści tracą wiarę we własną sprawczość w osiąganiu sukcesu życiowego i silniej akcentują wpływ czynników zewnętrznych w kształtowaniu swojej przyszłości, należy się spodziewać obniżenia ich aspiracji w zakresie wykształcenia i zawodu. Jeśli spada przekonanie o utracie kon- 
troli nad procesem osiągnięć, nie ma sensu stawiać przed sobą ambitnych planów, gdyż losowość (niskie prawdopodobieństwo) otrzymania nagrody (sukcesu życiowego) jest zbyt wysoka, aby nadmiernie się angażować.

\section{Subiektywna ocena roli wyższego wykształcania i wiara w powodzenie planów życiowych}

Aspiracje w ujęciu socjologicznym definiowane są najczęściej jako nadrzędne potrzeby, dążenia i zainteresowania jednostki lub grupy z wyraźnym zamiarem ich realizacji [Gołębiowski 1966]. Gołębiowski ma na myśli dążenia warunkowane przez hierarchię celów, które jednostka aprobuje i uznaje za istotne i które determinują jej życiowe plany. Sztompka [2004] określa natomiast aspiracje jako „(...) reguły, których przedmiotem są cele działania (...). Mówią one, co jest godne, słuszne, właściwe. (...) Wskazują, do czego ludzie powinni dążyć”. W tym sensie aspiracje obejmują przyszłe wybory - cele związane ze sferą kształcenia oraz aktualne wyobrażenia odnoszące się do zawodu.

Zdecydowana większość badanych maturzystów zamierza kontynuować naukę na studiach. W 2010 roku plany takie miało 87,3\%, a w 2015 roku - 83,4\% [Raport Matura i co dalej?]. Mimo niewielkiego spadku, wysokie aspiracje wśród białostockich maturzystów utrzymują się. Chęć uzyskania dyplomu może jednak służyć różnym celom. Dla części osób możne mieć w większym stopniu znaczenie instrumentalne, służące osiągnięciu określonych, wąsko rozumianych celów takich, jak prestiż czy wyższe dochody. Inni mogą dostrzegać jego wartość autoteliczną, a więc doświadczać satysfakcji płynącej z samego faktu posiadania wiedzy, rozwijania się. Na wykresie 1 zestawiono odpowiedzi (rozkłady procentowe) korespondujące $\mathrm{z}$ tymi zróżnicowanymi motywacjami. Testy istotności dla pomiarów przeprowadzono przy użyciu testu U-Manna-Whithney’a.

Choć, jak wcześniej wykazano, młodzież przejawia odmienne strategie planowania własnej kariery i różnorodne style podejmowania decyzji, zachodzi powszechna zgoda względem faktu, że studia przyczyniają się do rozwoju intelektualnego (ponad $80 \%$ wskazań w obu pomiarach) i mogą warunkować osiągnięcie życiowego sukcesu. Pozostałe stwierdzenia również osiągnęły poparcie ponad połowy badanych. Dotyczy to stwierdzeń, że studia zwiększają szanse na: uzyskanie wysokich zarobków, uzyskanie szacunku i uznania ze strony rodziców, uzyskanie pracy pozwalającej zreali- 
zować własne zainteresowania i pasje, uzyskanie dobrej pracy za granicą). Porównanie w dwóch punktach czasu pozwala zauważyć deprecjację wyższego wykształcenia jako katalizatora sukcesu i zaspokajania własnych aspiracji. Na każdym z dwunastu stwierdzeń poparcie dla roku 2015 jest niższe niż 2010 i różnice te są istotne statystycznie. Największe „tąpnięcie” nastrojów dotyczyło „uzyskania na studiach praktycznej wiedzy potrzebnej do wykonywania pracy zawodowej" (18,3\% punktów procentowych [pp.] różnicy), „uniknięcia bezrobocia” (14,6\%), „znalezienia wymarzonej pracy” (13,3\%), „uzyskania wysokich zarobków” (10,4\%) oraz „znalezienia pracy pozwalającej zrealizować własne zainteresowania i pasje” (10,4\%). Wszystkie powyższe stwierdzenia można zredukować do ogólnego wymiaru „sukcesu zawodowego" respondentów i wzmagającej się z biegiem lat niepewności, że ukończenie studiów zagwarantuje im przewagę konkurencyjną na rynku pracy.

Wykres 1. Studia jako inwestycja w przyszłość

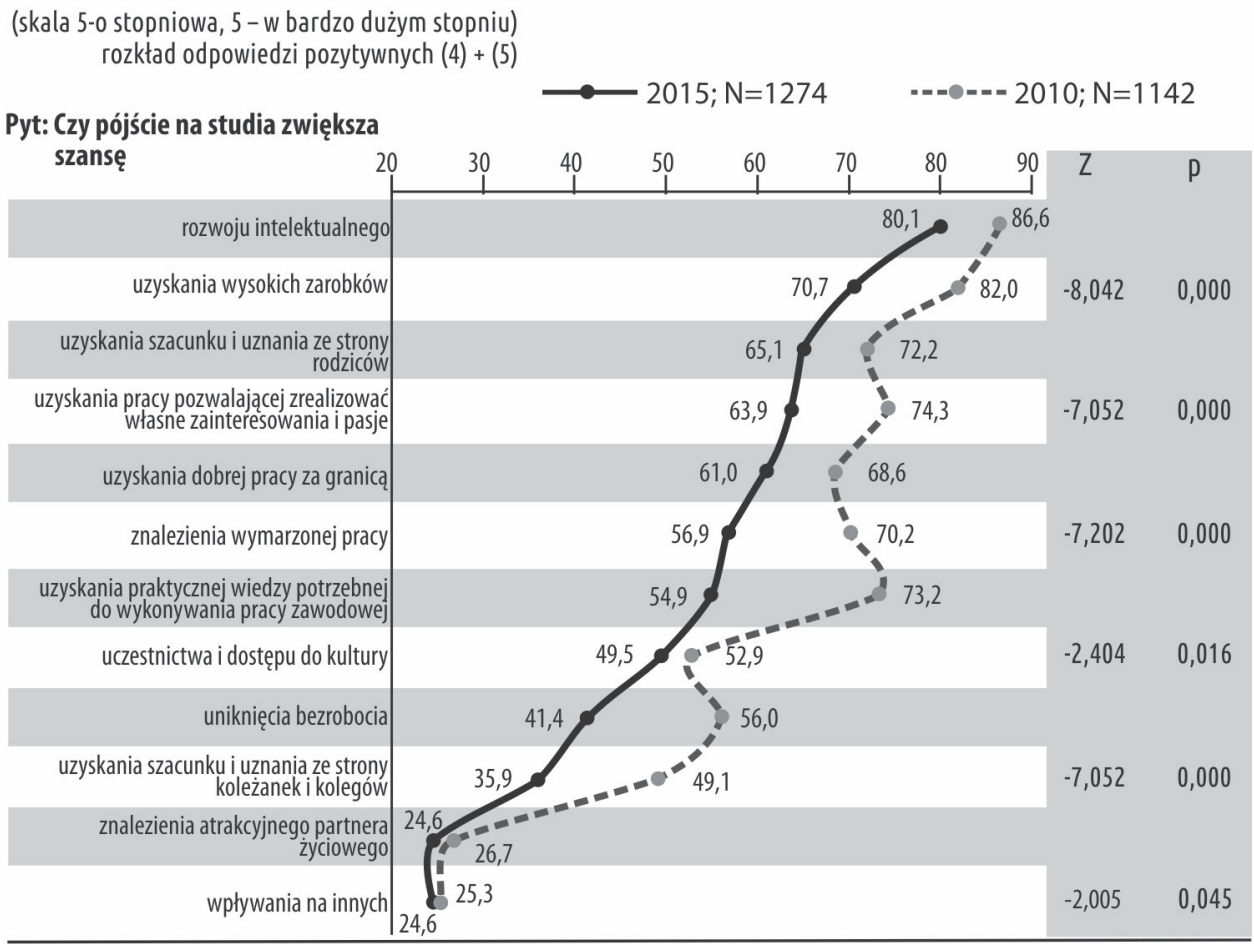

Źródło: Badania Matura i co dalej?, porównanie edycji 2010 i 2015. 
Wydaje się zatem, że duża dynamika rynku pracy, wysokie bezrobocie wśród osób rozpoczynających zawodową karierę wzmaga niepewność maturzystów, podsycaną brakiem gwarancji czy decyzja o studiowaniu pozwoli im na osiągnięcie wyżej wymienionych celów życiowych, zawodowych i osobistych. Inwestycja w wykształcenie jest kosztowna, a efekty tej inwestycji stają się coraz bardziej rozmyte. Indywidualne kalkulacje stają się zatem nieodzownym elementem podejmowania decyzji. Badani maturzyści kierują się jednak różnymi przesłankami: niektórzy potrzebują wsparcia otoczenia (rodziny, nauczycieli), inni odkładają decyzję na ostatni moment, nie przejmując się konsekwencjami (postawa carpe diem), pozostali zdają się na własną intuicję i nie rozpamiętują podjętych decyzji, choćby były nietrafne (postawa indywidualistyczna). Bez wątpienia ważnym czynnikiem jest też samoocena własnych zdolności, dotychczasowe wyniki w nauce, przewidywany wynik na maturze czy opinie na temat tego, jak wymagające mogą być podjęte studia. W ten sposób można na przykład wyjaśnić dlaczego, pomimo podzielanej powszechnej wiedzy, że do najbardziej perspektywicznych kierunków należy informatyka lub medycyna, to zdecydowana większość badanych, analizując własne predyspozycje, umiejętności i zainteresowania,wybiera inne fakultety. Rozdźwięk między oceną prospektywnych kierunków (uważanych za najbardziej pożądane na rynku pracy w przyszłości) a wysłanymi wyborami były bardzo słabo skorelowany $(r=213, p=000)$. Oznacza to, że młodzież decydując się na określone kierunki, niejako rezygnuje z zajmowania strategicznej pozycji na rynku pracy, oddając innym przywileje uzyskiwania wyższej pensji, prestiżu i wyższych szans na osiągnięcie zobiektywizowanego sukcesu życiowego.

W badaniu interesowała nas również ocena szans realizacji określonych scenariuszy w wieku 30 lat, kiedy jednostki zwyczajowo kończą lub skończyły już etap edukacji, mają już za sobą doświadczenie zawodowe oraz posiadają własną rodzinę. Chodziło zatem o określenie, na ile młodzi ludzie chcą realizować konwencjonalny cykl życiowy i związaną z nim hierarchię celów:ukończenie studiów, wejście na rynek pracy, założenie rodziny. Maturzyści proszeni byli o ocenę prawdopodobieństwa realizacji każdego ze scenariuszy ujętych na wykresie 2 . Oceny prawdopodobieństwa dokonywali na 11 punktowej skali, gdzie 0 oznaczało „niemożliwe”, a 10 „na pewno”. Pytanie zaś brzmiało „Oceń, jak prawdopodobne jest, że gdy będziesz miał 30 lat, będziesz..." 
Wykres 2. Wiara w realizację planów życiowych

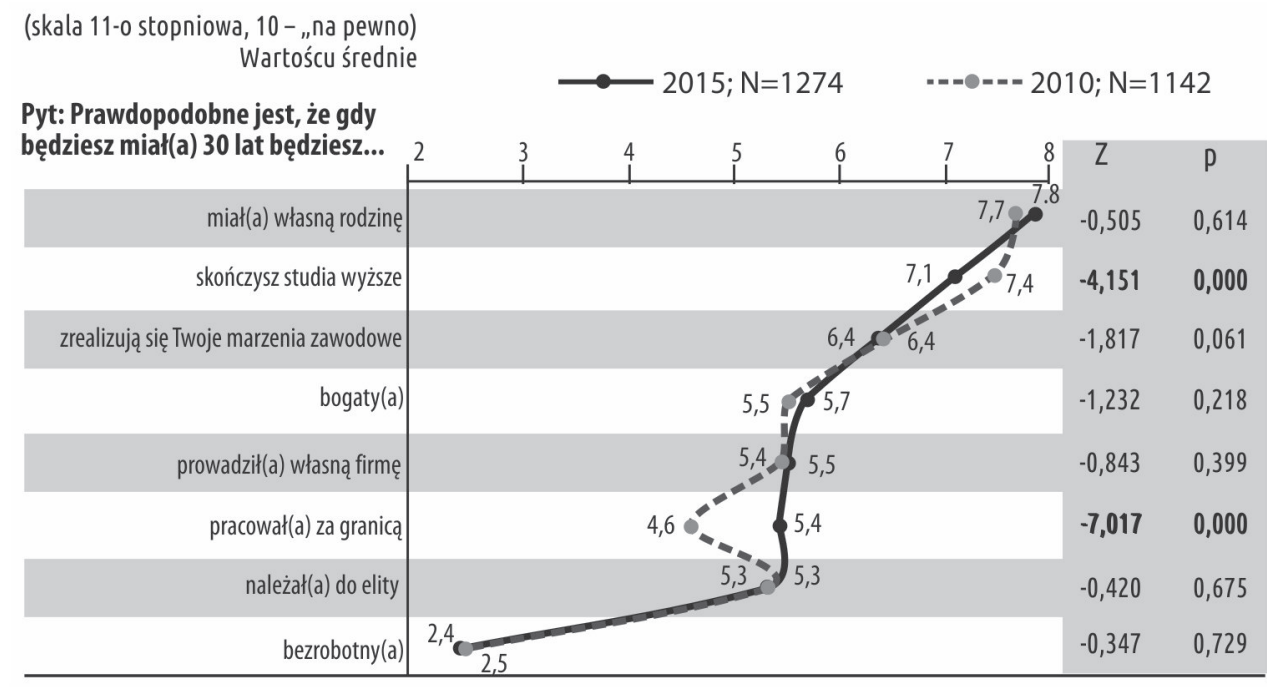

Źródło: Badania Matura i co dalej?, porównanie edycji 2010 i 2015.

Badane dwie kohorty maturzystów miały dość zgodne wyobrażenia o szansach realizacji celów. Największe prawdopodobieństwo przypisują założeniu własnej rodziny, najmniejsze byciu bezrobotnym. Na drugim miejscu znalazło się przekonanie o ukończeniu studiów, choć zachodzi tu istotna statystycznie różnica, ponieważ maturzyści w 2015 roku wykazywali mniejszą wiarę w realizację takiego scenariusza. Ów spadek prawdopodobieństwa związany jest zapewne $\mathrm{z}$ opisaną powyżej utratą przeświadczenia, że studia ułatwiają znacząco osiągnięcie w życiu sukcesu. Maturzyści z umiarkowanym optymizmem zapatrują się na możliwość realizacji zawodowych marzeń. Osiągnięcie bogactwa, przynależność do elity oraz prowadzenie własnej działalności wydają się być najbardziej indyferentne, niejednoznaczne i nieprzewidywalne, czego dowodem jest średni wynik w obu pomiarach, oscylujący blisko środka skali (między 5,3 a 5,7). W 2015 roku wzrasta natomiast istotnie odsetek osób deklarujących, że w wieku trzydziestu lat będą pracować za granicą. Wzrost zainteresowania wyjazdem można wyjaśnić na kilka sposób. Po pierwsze,kolejne roczniki młodzieży nabywają większe kompetencje w zakresie języków obcych, dzięki czemu nie boją się pracy w innym kraju. Po drugie, może się to wiązać z dość dużymi tradycjami migracji na Podlasiu, dzięki którym powstały sieci kontaktów 
z osobami przebywającymi już za granicą. Wyjazd nie musi odbywać się „W ciemno”. Po trzecie, postawa promigracyjna może być konsekwencją silnej niepewności panującej w czasie realizacji badania na krajowym rynku pracy oraz znaczącym spadkiem wiary w gwarancję osiągnięcia sukcesu dzięki ukończeniu studiów. Stąd wzrastające w młodszej kohorcie przekonanie, że życie niejako „zmusi” ich do wyjazdu. Duże prawdopodobieństwo wyjazdu nie wiąże się z przekonaniem o podjęciu tam profesji zgodnej $\mathrm{z}$ kierunkiem studiów. Dowodem tego jest spadająca na przestrzeni lat wiara, że studia pozwolą na znalezienie dobrze płatnej pracy za granicą (wykres 1).

\section{Rola czynników wewnętrznych i zewnętrznych w realizacji życiowych planów na przestrzeni lat}

Sukces życiowy determinowany jest rozmaitymi czynnikami: wewnętrznymi, na które mamy wpływ (zdobyta wiedza i wykształcenie, spryt), tymi które dziedziczymy (uroda, majątek), a także zewnętrznymi, niezależnymi od naszych wysiłków, ale mogącymi kształtować nasze aspiracje (kondycja gospodarki, miejsce urodzenia). Czynniki te są w różnym stopniu skorelowane i nie jest łatwo rozstrzygnąć o ich jednostkowej wadze w realizacji życiowych planów. Określenie ich wpływu dodatkowo utrudnia perspektywa czasowa, ponieważ nagrody za poniesiony wysiłek mogą być odroczone w czasie.

Niemniej przekonanie o istotniejszym wpływie czynników wewnętrznych na osiąganie życiowych planów świadczyć będzie o większym poczuciu kontroli własnego losu. Natomiast akcentowanie wymiaru zewnętrznego oznaczać będzie brak poczucia sprawstwa i utratę przekonania o wpływie na własne życie.

$\mathrm{Na}$ przestrzeni pięciu lat, rozpatrując rolę czynników wewnętrznych w realizacji planów życiowych, deprecjacji uległo jedynie „własne wykształcenie", choć nadal charakteryzowało się ono wysokim odsetkiem wskazań (spadek z 87,7\% w 2010 roku do 83,8\% w 2015 roku). Kolejny raz potwierdził się spadek atrakcyjności edukacji jako kluczowego czynnika osiągnięcia sukcesu życiowego.Pozostałe czynniki wewnętrzne oceniane są przez maturzystów jako niezwykle ważne i utrzymywały się na stałym poziomie od 2010 roku ze wskazaniami powyżej 80\%. Jedynie wdzięk i urok osobisty, traktowane są jako mniej istotny wymiar wpływający na wypełnianie życiowych aspiracji. 
Wykres 3. Rola czynników w realizacji planów życiowych

(skala 5-o stopniowa, 5 - bardzo ważne)

rozkład odpowiedzi pozytywnych (4) + (5)

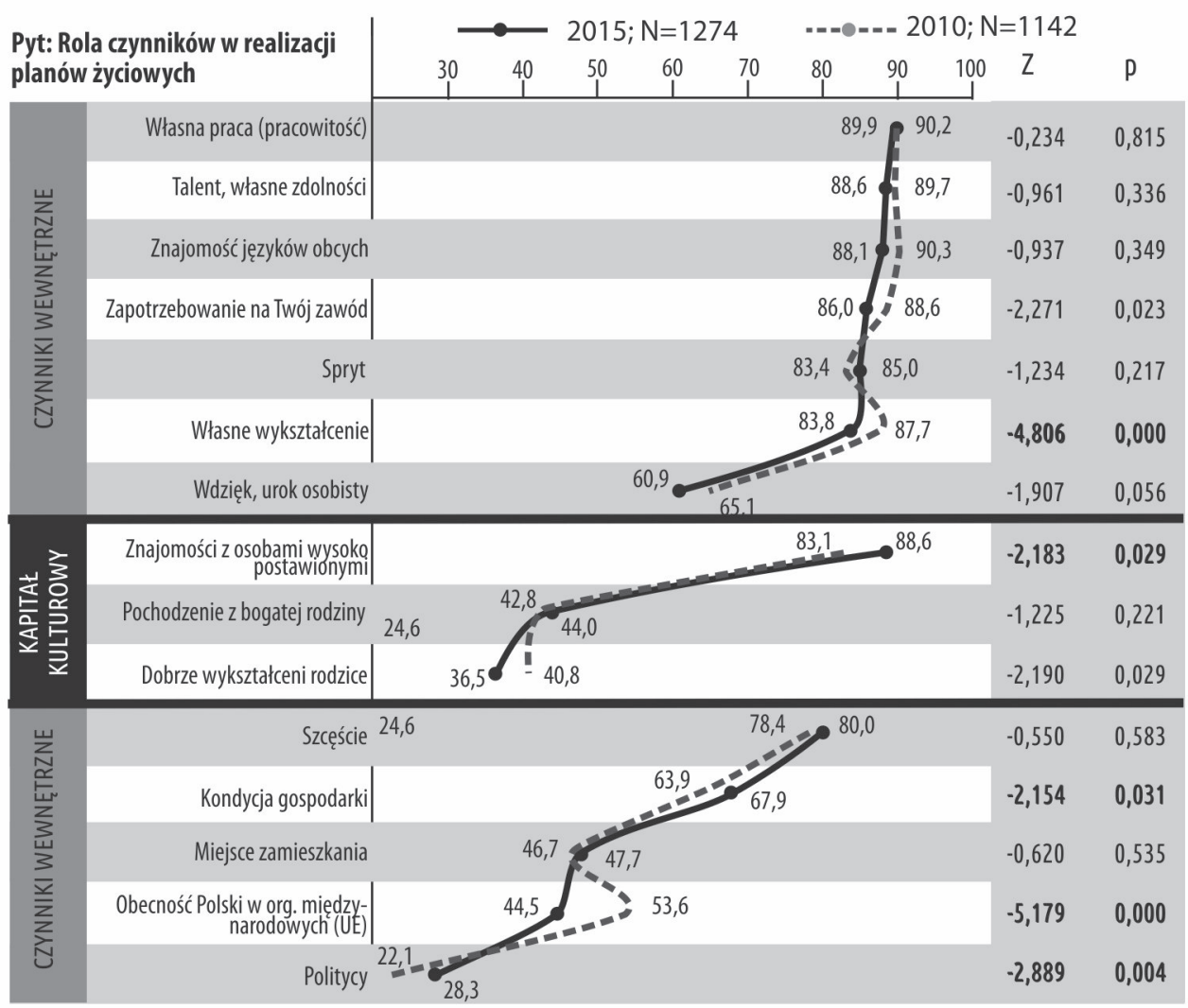

Źródło: Badania Matura i co dalej?, porównanie edycji 2010 i 2015.

Analizując kolejną grupę czynników, określoną tu „kapitałem kulturowym" widać, że w przekonaniu maturzystów ważne w urzeczywistnieniu życiowych zamierzeń okazują się „znajomości z wysoko postawionymi osobami". Wymiar ten nabrał znaczenia w okresie objętym badaniem - w 2015 roku odpowiedź taką wybrało 88,6\% badanych, a pięć lat wcześniej 83,1\%.Wyraźnie mniejsze znaczenie ma natomiast, zdaniem młodych osób, pochodzenie z bogatej rodziny, czy też dobrze wykształceni rodzice. Spoglądając na rzeczywistość oczami ludzi wchodzących za chwilę w dorosłość widać, że realizacja własnych planów uzależniona jest 
niemal w takim samym stopniu od własnej pracy, co posiadania kontaktów z przedstawicielami wpływowych środowisk społecznych.

Ostatnia grupa czynników zewnętrznych, choć nie uzyskuje tak wysokich wskazań jak poprzednie wymiary, uwidacznia wzrost przeświadczenia, że wiele w życiu zależy od czynników, na które młody człowiek nie ma wpływu lub jego wpływ jest minimalny, na przykład kondycji gospodarki (istotny wzrost wskazań) lub polityków, a w szczególnym stopniu od szczęścia. Dodatkowo, widać wyraźny spadek przekonania, że (z 53,6\% w 2010 roku do 44,5\% w 2015 roku) obecność Polski w Unii Europejskiej może przyczynić się do realizacji życiowych planów jednostki. Być może związane jest to $\mathrm{z}$ ostudzeniem proeuropejskiego entuzjazmu wiązanego $\mathrm{z}$ przekonaniem, że obecność Polski w tej organizacji otwiera szerokie perspektywy realizacji planów życiowych. Postawa ta wpisuje się też w obserwowany w ostatnich latach wzrost nastrojów pronarodowościowych, które pojawiają się w kontrze do panującego po wstąpieniu Polski do UE euroentuzjazmu.

Kwestią podsumowującą aspiracje życiowe maturzystów było pytanie dotyczące konkretnego wyboru: możliwości podjęcia przez nich pracy zawodowej za 1,5 tysiąca złotych „na rękę” i konieczności zakończenia edukacji. Celem użycia tego wskaźnika było zbadanie, na ile nagroda w postaci dość przeciętnych zarobków (obecnie stanowiących płacę minimalną) otrzymana "dziš" okaże się atrakcyjniejsza niż długookresowa inwestycja w dalszą edukację, której efekt zwróci się w przyszłości. Innymi słowy interesowało nas przez jaką część badanych kwota ta może być uznana za ekwiwalent inwestycji w dalszą edukację. Przypomnijmy, że zdaniem maturzystów edukacja znacząco wpływa na osiąganie życiowych planów i aspiracji (wykres 3), ale jednocześnie zauważalny jest widoczny spadek wiary w przydatność studiów w zdobywaniu dobrze płatnej pracy.

Tabela 3. Deklaracja chęci podjęcia pracy za 1,5 tysiąca złotych netto kosztem studiów

\begin{tabular}{|l|c|c|}
\hline Wyszczególnienie & $\mathbf{2 0 1 5}$ & $\mathbf{2 0 1 0}$ \\
\hline Zdecydowanie tak & 4,2 & 4,0 \\
\hline Raczej tak & 15,9 & 14,5 \\
\hline Raczej nie & 44,4 & 41,4 \\
\hline Zdecydowanie nie & $\mathbf{3 5 , 4 -}$ & $\mathbf{4 0 , 1 +}$ \\
\hline Razem & 100 & 100 \\
\hline
\end{tabular}

+/- istotne różnice na poziomie ufności 95\%; N=1042 w 2015; N=1009 w 2010 r.

Źródło: Badania Matura i co dalej?, porównanie edycji 2010 i 2015. 
Rozkład procentowy (tabela 3) pokazuje, że gdy zagregujemy odpowiedzi aprobujące scenariusz podjęcia pracy zawodowej za 1,5 tysiąca złotych („zdecydowanie tak” i „raczej tak”), to pomimo upływu czasu, w obu pomiarach blisko co piąty maturzysta gotów był zrezygnować z dalszej edukacji. W 2015 roku istotnie spadł odsetek osób zdecydowanie odrzucających ewentualność rozpoczęcia pracy kosztem edukacji. Gdy uwzględnimy deprecjację pieniądza (inflację) i podnoszenie w kolejnych latach płacy minimalnej, okazuje się, że mniej wartościowe niż w 2010 roku wynagrodzenie jest równie atrakcyjne po pięciu latach. Po raz kolejny potwierdzona zostaje teza o spadku przekonania, że studia mogą znacząco przyczynić się do osiągnięcia sukcesu życiowego i zaspokojenia aspiracji zawodowych i finansowych. Dlatego pewna frakcja młodych ludzi wybiera gwarancję pewnej, choć niekoniecznie atrakcyjnej pensji (teraźniejszości) w zamian za być może wyższą, choć niepewną nagrodę jaką mogą zagwarantować studia w odległej przyszłości.

\section{Podsumowanie}

Zaprezentowany w artykule porównawczy wycinek badań Matura i co dalej? pozwolił uchwycić przemiany w zakresie subiektywnej oceny szans na realizację własnych aspiracji edukacyjnych, zawodowych i życiowych w dwóch kohortach maturzystów. Okazało się, że nastąpiła zauważalna deprecjacja wartości studiów jako czynnika gwarantującego osiągnięcie sukcesu życiowego. Widać to na każdym ze zdefiniowanych wymiarów: zawodowym (zdobycie satysfakcjonującej i lepiej płatnej pracy; uniknięcie bezrobocia) oraz społecznym/ afiliacyjnym (uzyskanie szacunku i uznania ze strony znaczących innych). Ponadto, spadło przekonanie młodzieży, że w ogóle ukończą studia, a wzrosła wiara w konieczność podjęcia pracy za granicą. Istotnie przybywa osób, które wątpią we własną sprawczość oraz wyrażają przekonanie, że życia nie da się zaplanować, a sukces zależy często od przypadku, a nie racjonalnych i przemyślanych decyzji. Stąd, maturzyści w 2015 roku, w odróżnieniu od kohorty z 2010 roku, jako determinanty realizacji własnych planów (aspiracji), istotnie częściej wskazują czynniki zewnętrzne: kondycję gospodarki, polityków, znajomości lub powiązane z kapitałem kulturowym: znajomości z wysoko postawionymi osobami.

Dokonane obserwacje otwierają szerokie pole do dyskusji i stanowią zachętę do kontynuacji badań nad omawianymi kwestiami. Mogą również służyć do dokonania analiz porównawczych, zarówno w wymiarze poziomym (z maturzystami z innych regionów Polski) oraz pionowym (ze studentami I i II stopnia). 


\section{ANEKs}

\section{O badaniu Matura i co dalej?}

Dane $\mathrm{w}$ przedmiotowym artykule pochodzą z cyklicznego badania Matura i co dalej? realizowanego przez Instytut Socjologii i Kognitywistyki w Białymstoku, począwszy od 2010 roku, kiedy miał miejsce pierwszy pomiar. Kolejne powtórzono w 2013 i 2015 roku.

Badanie obejmowało każdorazowo swoim zakresem populację uczniów klas maturalnych w szkołach ponadgimnazjalnych. Ze względu na brak informacji o liczbie i liczebności klas w poszczególnych placówkach, zamierzeniem autorów projektu było zrealizowanie próby wyczerpującej, czyli dotarcie do każdej szkoły ponadgimnazjalnej w stolicy województwa podlaskiego i realizacja ankiety audytoryjnej we wszystkich klasach maturalnych.Dzięki zastosowanemu podejściu uwzględnione zostały nie tylko typy szkół maturalnych (liceum ogólnokształcące, liceum profilowane, technikum oraz szkoła zawodowa), ale również wszelkie możliwe profile kształcenia, które pozostają obecnie bardzo zróżnicowane w obrębie poszczególnych szkół i są niekoherentne na poziome międzyszkolnym.

Celem projektu była eksploracja kwestii odnoszących się między innymi do dostępu maturzystów do informacji wpływających na decyzje edukacyjne i zawodowe, perspektyw oraz planów zawodowych i edukacyjnych, prezentowanych stylów życia i wartości, kryteriów wyboru wyższej uczelni, wpływu środowiska na podejmowane wybory edukacyjne, subiektywnych szans osiągnięcia sukcesu edukacyjnego i zawodowego.

\section{Bibliografia}

Aczel A. (2000), Statystyka warządzaniu, Warszawa.

Bańka A. (2005), Rozwój i zastosowanie teorii psychologicznych we współczesnym doradztwie karier w kontekście integracji transkulturowej, [w:] Psychologia bliżej życia, t. 2 (23), red. K. Popiołek, Katowice.

Bourdieu P. (2006), Reprodukcja. Elementy teorii systemu nauczania, z Jean-Claude'em Passeronem, przeł. E. Neyman, Warszawa.

Gołębiowski B. (1966), Społeczno-kulturalne aspiracje młodzieży. Studium socjologiczne, „ZG ZMW”, z. V.

Hildebrandt-Wypych D. (2011), Społeczne konstrukcje sukcesu życiowego wśród młodzieży niemieckiej, „Teraźniejszość - Człowiek - Edukacja”, nr 1(53).

Johnson A. G. (1997), The Blackwell Dictionary of Sociology, Oxford. 
Pinquart M., Silbereisen R. K. (2010), Patterns of Fulfillment in the Domain of Work, Intimate Relationship, and Leisure, "Applied ResearchQuality Life, Quality Life", nr 5.

Poleszczuk J. (2013), Trudne wybory i decyzje edukacyjne młodzieży: czy młodzi ludzie potrafia podejmować racjonalne decyzje?, [w:] Obrazy dziecinstwa i dorastania: wybrane problemy teoretyczne i empiryczne, red. R. Michalak, M. Wieczorek, Poznań.

Reber A.S. (2000), Słownik psychologii, Warszawa.

Szymański M. (2010), Ścieżki kariery studentów socjologii UAM, Kraków.

Sztompka P. (2004), Socjologia. Analiza Społeczeństwa, Kraków.

Pozostałe źródła:

http://soc.uwb.edu.pl/images/matura/Raport_Matura_i_co_dalej_Edycja_2010.pdf, [20.02.2017].

http://rynekpracy.org/x/946883, [20.02.2017].

\section{SUMMARY}

Educational, professional and life aspirations of Bialystok high school graduates. Comparative analysis of decision strategies and subjective chances of life success over the years 2010-2015

This article cover the analysis of subjective chances for life success, measured by the level of educational and professional aspirations, based on a time perspective. The first and third wave of longitudinal study conducted in Bialystok "Maturity exam and what next?" will be compared to verify, if there have been significant changes graduates' decision-making strategies and in probability of achieving assumed plans.

KEYWORDs: high school graduates, educational aspirations, professional aspirations, life success, decision strategies 